\title{
Rumor, Reputation, and Sensation in Tess of the d'Urbervilles
}

\section{DANIEL WILLIAMS}

Rumor, so they say, is a species of noise. Echoing behind its many names and targets we find a cache of sonic terms, from the Latin rumor to the French bruit, both adopted by English to identify common talk, that which is "noised abroad." A range of often-cognate terms can designate at once the content embodied in public chatter or unconfirmed gossip, the vehicle of such reports, the alleged referent, and even the voices of natural entities, such as the howling of wind or the murmuring of a stream. ${ }^{1}$ As a self-sustaining, non-subjective entity that spurs its own movement and need not be linked to any concrete speaker or verifiable source, rumor whispers in the shadowy space beyond the horizon and roars in terrible proximity to the individuals who come within its sights. It is that "wide sprinkling of conjecture," as Thomas Hardy puts it, "wherein no man [knows] the exact truth" (Woodlanders 223). Personifications of rumor are notably amorphous-from Rabelais's Ouy-dire (Hear-say) to Shakespeare's Rumour, "painted full of tongues" (Henry IV, Part 2, Induction, o.s.d.)-all hearkening back to Virgil's terrifying depiction of the goddess Fama, "than which no other evil is more swift: / She gains strength in movement, and vigor as she goes." ${ }^{2}$ Since rumors "exist in radical separation from individual speakers" (Gross 52), their attacks on name and reputation become all the more devastating for being indefensible, for "hearsay evidence" is inadmissible in courts of law and no agent can be charged with a crime. ${ }^{3}$

Despite this profusion of examples, rumor often eludes the critical attention that would apprehend it. Attending to the vague distances in which rumor operates might distract from plot and narrative mechanics closer at hand; only rarely does it find voice in a concrete speaker; and its lack of verifiability frustrates. ${ }^{4}$ Since

1 I discuss philological issues in greater detail below; for provisional definitions, see Kenneth Gross 45; OED, s.v. "rumour, n."; Henry George Liddell and Robert Scott, s.v. "orumagdós" and "ōrúomai"; Charlton T. Lewis and Charles Short, s.v. "rūmor, -ōris, m."; P. G. W. Glare, s.v. "rūmor, -ōris, m."; and etymological discussions in Alfred Ernout and Antoine Meillet and in Michiel de Vaan, both s.v. "rūmor."

2 "Fama, malum qua non aliud uelocius ullum: / mobilitate uiget uirisque adquirit eundo" (Aeneid IV, 11. 173-74; my translation). Hardy had a copy of John Dryden's translation (Hardy, Notebooks 2: 562-63), which embellishes these lines: "Fame, the great ill, from small beginnings grows- / Swift from the first; and every moment brings / New vigour to her flights, new pinions to her wings" (Virgil, Works IV, 11. 252-54). In a notebook in use from the 1870s until 1888, Hardy writes that the mourning fields of Aeneid VI "are crowded with ladies of a lost reputation" (Notebooks 2: 287). For a discussion of personifications of rumor, see Gross 53, 59.

3 I focus on broadly negative aspects of rumor, but it may be conceded that, under certain conditions, there is a "good gossip" that "enlarges the world" in a quite different sense and counts as "healing talk" (Spacks, "In Praise" 25-27); see generally Patricia Meyer Spacks, Gossip.

4 See Blakey Vermeule's claim that gossip in literature "pushes the action deeper into the background" (104).

Novel: A Forum on Fiction 46:1 DOI 10.1215/00295132-2019128 $\quad$ (c) 2013 by Novel, Inc. 
rumor bears a "nontrivial relation to truth that eludes the problem of verification and falsification and claims to be closer to truth than factual adequation," its epistemological status is always vague: "[I]n itself it accounts for the possibility of an error that does not entirely undermine the definition of truth" (Agamben 8). To speak of rumor or gossip would seem to mimic their patterns, to recall the "structure of hearsay" in the "denunciation of hearsay," not so much because one might take up the slack of what gossip proffers as "fact," but rather because "both hearsay and its denunciation consist in speaking about nothing but speaking" (Fenves 14). To speak of rumor without repeating its claims is to perpetuate new rumors or to denounce old ones, thereby speaking "about the mode of speaking that no longer speaks about things but only about speaking" (ibid.). Such discourse may easily fall to replicating rumor's arrangement, becoming "report" or "chatter," playing on the "pipe / Blown by surmises, jealousies, conjectures" (Henry IV, Part 2, Induction, 11. 15-16). To take rumor as a critical category threatens to hollow out analysis as just so much gossip. Or so they say.

Yet if rumor can damage "by converting people into fictions" (Spacks, "In Praise" 36), then its status within a fictional world, however vexing, still demands notice and explanation. While heeding its evidentiary obstacles and moral aftermath, this essay intends to capture rumor as one driving motif in the work of Thomas Hardy, focusing on its narrative dynamics in Tess of the d'Urbervilles (1891). ${ }^{5}$ Through a precarious alliance of social representation and bodily registration, rumor operates as a compelling and often covert force in this novel, undergirding a plot more often read as governed by the internal, moral dynamics of shame and the external constraints of fate. My reading will be concerned with the moments where Hardy points to the acceleration and threat of rumor and the parallel heightening of sensation it compels. In the first section, I examine the relationship between the movement of characters and the "repute" they magnify by traveling around in social space. Although movement away from and then back to a place alternately dilates and contracts the space of repute, the initial exposure remains an ineradicable social fact. The movement of characters sets a rhythm for rumor, I argue, at once opening and reticulating the paths along which hearsay travels and becomes conventionalized as "opinion" - thereby forging unexpected connections across different social spaces-and then retreats along with the person who uneasily awaits discovery. In the second section, I pay keener attention to the internal, bodily manifestations of this social dynamic, to what might be called the physiology and sensation of rumor - the events it occasions in the body and the awareness of such events, the sensation of causing a "sensation." ${ }^{16}$ Rumor encourages such

5 These topics have been underappreciated rather than unnoticed in the criticism. For a reading of gossip in Jude the Obscure, see Jan B. Gordon, "Gossip" 48-52, 62-65; for comments on gossip in Tess of the d'Urbervilles, see Tess O'Toole's discussion of "exposure" (88-89) and Gordon's suggestion that gossip is "one of the ways in which Tess continues to be shaped by history" and by "the language of the past" ("Origins" 372).

6 This latter usage (see OED, s.v. "sensation, n.," def. 3, esp. 3c) was recent in Hardy's lifetime. As a sub-definition of "excited or violent feeling," defined by the $O E D$ as if it were itself relaying an item of gossip_- "An event or a person that 'creates a sensation"'- this usage emerges in the 1860s. 
states on account of its deep and sensed link with our corporeal existence. Quickening the pulse, raising a blush, inducing the acute and stinging feeling of being watched or the uncanny sense of being within others' hearing, rumor turns social appraisal, real or imagined, into moral emotions and bodily awareness quite apart from the verifiability of the occasioning events. I contend that Hardy's metaphors for the felt aspect of fearing discovery, whether visual or aural, show rumor taking on a life of its own in the body, arrogating to itself the veracity it cannot attain in the social world by means of physiological states and sensations that register such states. In the final section, I turn to rumor's attack on one's "name." I show how, both within the boundaries of Tess of the d'Urbervilles and beyond them, in his poetry, Hardy relocates that most external index of social presentation (a name) within the contours of bodily sensation, making public slander even further a matter of private sensation and turning the pressures of fate inescapably inward. ${ }^{7}$

Since much of my analysis will track the accumulation and repetition of rumor's vocabulary-which I will use somewhat indiscriminately, as befits the object-it may be well to offer a philological disclaimer at the outset. I have already indicated the etymological provenance of rumor from the Latin and earlier roots, although the ultimate origin of this semantic field is somewhat unclear. ${ }^{8}$ In his Etymologies, Isidore of Seville (d. 636) discusses the Latin fama ("report") under the rubric of infamium, as one of a set of punishments given in the law and articulates the underlying contradiction in trying to name whatever seeks to undermine the veracity of naming as such, noting

infamy [infamium], as if it were "without good report" [bona fama], and "report" is so called because by speaking [fanda], that is, talking, it roves about, creeping [serpens] through the grapevine of tongues and ears. The term fama is also appropriate for both good and evil things, for "report" is sometimes of good fortune, as in "illustrious report," which is praise. . . . Report does not possess a trustworthy [certilocum] name, because it is especially untruthful [mendax], either adding many things to the truth, or distorting the truth. It lasts just as long as it is not put to the test, but whenever you put it to the test, it ceases to be, and after that is called fact [res], not report. (Etymologies 124; Etymologiarum 1: 5.27.26-27)

Whether operating under designs of praise or malice, report acquires its own serpentine mobility and can initiate damage just as much in its presence (fama) as in its privation (in-famium). Fama's especial falsity and uncertainty serve to destabilize its own name just as it would undermine the names of others, and if it does disappear under the pressure of examination, this testing must convert the diffuse monstrosity (Isidore naturally invokes Virgil here) into res, "fact." Importantly, fama is related to fate in that both emerge from the Latin fari, "to talk" — what

7 This analysis, I believe, might be expanded to the narrative systems of other novels where rumor lurks in the background or steers key elements of the plot, as it does in Hardy's The Mayor of Casterbridge (1886), The Woodlanders (1887), and Jude the Obscure (1895).

8 Dictionaries of etymology cannot decide on this issue: Ernout and Meillet, as well as Vaan, give roots that mean "to howl," "to roar," and "to shout." 
is "fated" is, as it were, what is already spoken for. ${ }^{9}$ In approaching Hardy with this background in mind, I shift the lens of interpretation beyond accounts that see fate (hence "fatalism" or "determinism") as the engine of the plot. A malicious and intractable design does operate in this novel. Paying attention to its internal narrative dynamics - its covert social momentum and its localization in the bodies and sensations of characters-allows us to appreciate how rumor's contingent reports come to feel to characters like necessary facts governing their bodies, their social and moral identities. ${ }^{10}$ If fate is the engine, then rumor is its fuel. And if, as Hardy himself suggested, "the forces opposed to the heroine were allegorized as a personality" (F. E. Hardy 244), perhaps we do better to see the springs of these forces beyond the machinations of fate, in the intertwining pressures of that more devious, cognate relative-Fama.

\section{The "Radius of Movement and Repute": Rumor and Social Space}

In Tess of the d'Urbervilles, repute operates at first in a small space, functioning in a mild and comical fashion. Tess offers to go to Casterbridge in order to keep her father's irresponsible drunkenness a private matter: "[L]etting everybody know the reason-such a thing to be ashamed of!" (40). ${ }^{11}$ When she comes back from her unpleasant stay at the d'Urberville estate, the boundaries within which her return comes to light diminish it to the innocuous stature of local news, which is "rumoured abroad, if rumour be not too large a word for a space of a square mile" (118). At this point, Tess is simply a person to be regarded with "fascination" and "great curiosity" (118), "the most interesting personage in the village to many," even though she is also caricatured as the sign of an "event" that makes her, for some, little but "a social warning" (129).

When Tess receives word of the opportunity at Talbothays dairy, an initial disappointment is voiced on her behalf: "It was not quite so far off as could have been wished; but it was probably far enough, her radius of movement and repute having been so small. To persons of limited spheres miles are as geographical degrees, parishes as counties, counties as provinces and kingdoms" (140-41). The agentless character of this surmise-“"could have been wished": by whom?-suggests the formlessness of that which looks to damage repute, the sum of vague threats

9 See Thelma Fenster and Daniel Lord Smail 10-11 for further cognates and a brief discussion of the Indo-European root $b h \bar{a}$, "to speak," which leaves important deposits in English words beginning pha- and ending - phone and -fess and is importantly cognate with ban and banns, via Old English bannan, variously "to summon" and "to proclaim" (OED, s.v. "banns, n." and "ban, v.").

10 See Bernard Williams 103-29 for the notion of a "necessary identity," a version of necessity whose compulsive force is exerted between the internal, moral pressures of shame and the external constraints of divine forces, thereby making even the social identity of an agent into a "necessary identity," felt as an unavoidable, even "natural" compulsion.

11 Further parenthetical references are drawn from the critical edition of Tess of the d'Urbervilles (see Grindle and Gatrell, eds.), which takes the manuscript as its copy-text; references to page numbers with notes or variants are to the apparatus criticus of this edition. 
to an unblemished name and to "good report" (280). ${ }^{12}$ A dramatic dilation of the world obtains when Tess moves a mere twenty miles away from Marlott, with a similarly dramatic expansion of her "radius of movement and repute." Her previously curtailed "sphere" is exploded in a world where women display "the bold grace of wild animals - the reckless, unchastened motion of women accustomed to unlimited space" (249; emphasis added). The uncomfortable word "chaste" may lurk in the different semantic register of "unchastened" here. Consciously, Tess tries to repair her family's current fortunes, which she takes to have been damaged by her loss of a "chaste" status; unwittingly, she is trying to avoid her family's historical fall, a thought with which John Durbeyfield was earlier told to "chasten" himself (16). Much later in the novel, as Tess travels to Emminster and looks down from the escarpment at the Vale of Blackmoor, the same language of spatial contrast is repeated. In place of "the great enclosures of a hundred acres" (407), the Vale of the Great Dairies where the "world was drawn to a larger pattern" (148), she sees the "little fields below her of less than half-a-dozen acres" (407), the Vale of the Little Dairies which had been her ambit of operation, "save during her disastrous sojourn at Trantridge" (148). This reminder of her prior, diminutive space of action, however, mocks Tess's inability to contract her space of reputation, to rein in her "radius of movement" and thereby bring her "repute" under control. Having worked in the dairies, which are themselves "renowned" (148), she is unable to retract the exposure of her name and will end by recapitulating the sorry fortunes of her "family of renown" (268), a fate to which she is driven by rumor.

This enlarging of the space of social action, I am suggesting, brings into play the growing menace, the swirling and swelling threat of Fama, which increases its pressure and eventually carves out the state of apprehension that prompts Tess's confession to Angel Clare. Hardy suggests that her fears are not entirely without ground, since the key reputations in the novel do take flight and trespass across the boundaries of different worlds. For instance, Alec's "reputation as a reckless gallant and heartbreaker" early on begins "to spread beyond the immediate boundaries of Trantridge" (118) and sets up bridges across various social and narrative spheres. Alec will be explicitly linked to the world of Angel via an item of gossip concerning the former's "career" that reaches-"come[s] to the ears of" (166)-the latter's clerical father. In a similar way, the sign-painter's conversion by Mr. Clare might be seen as entailing a more significant genealogy for the crimson accusations that roam around the Wessex countryside, as though behind the painted slogans Tess were to imagine the views of Angel's father. Thus, from the small space of Marlott to Trantridge and Talbothays, rumor traces the circles of "movement and repute" as they are enlarged and begin to cross paths with one another. Hardy's acute awareness of this dynamic can be measured by the efforts he often takes, in revisions, to render vague or inexplicit the threat of hearsay. When Tess first travels to Talbothays, she accepts a ride with a farmer traveling to Weatherbury; in manuscript revisions that he then deleted, Hardy makes one of her

12 In the King James Version to which Hardy customarily referred, the phrase "good report" is often repeated (e.g., 2 Cor. 6.8; Phil. 4.8; 1 Tim. 3.7). The word report may also apply to the sound of a gun (Woodlanders 114). 
motivations clear: "The gossiping interior of a carrier's tilt was what she shrank from just now" (146, app. crit.). He allows John Durbeyfield a striking tonality in one manuscript paragraph not included in 1891, to the effect that "the snaring of his eldest daughter . . . made him smart whenever he thought of it. . . It was not the fact, however, but gossip about the fact which mortified him" (130, app. crit.). ${ }^{13}$

The movement of Tess, first twenty miles east to the estate of the Stoked'Urbervilles and then twenty miles or so south to the dairies, sets a back-and-forth dilation as the general rhythm of other characters in the novel. At the same time, this movement indicates how rumor follows her along these pathways, connecting different strands of the plot as individuals themselves begin to drift. Indeed, Tess of the d'Urbervilles offers perhaps the most complete instances of John Bayley's fine observation that there are "no homes in Hardy" - that few "people in whom he is interested in the novels possess a proper home" and that, in a related manner, Hardy's "passion for the past is for a homeless place, where nothing has happened but the invisible certainties of event" (19). We may pay most attention to Tess, but both Angel and Alec are "cut off from any fixed community," as Tony Tanner has noted (230). They have both "broken away from traditional attitudes and dwellings" and are thus "drifters of the sort who have an unsettling, often destructive impact" (ibid.), partly on account of the fact that wandering, drifting individuals become at once vehicles for and objects of gossip_of the rumor that moves with them and finally exceeds the sum of all their movements.

In traveling and thus opening the possibility of discovery, pressing back the borders within which her past may gradually come to light, Tess recognizes that she will be unable to stay hidden in "some nook which had no memories" (140), where there might be "no invidious eyes upon her" (149). Various incarnations of this desire can be traced in textual variants, as in one manuscript reading that has Tess looking "to lead an inner life apart from that of the world around her; to occupy a mental and emotional convent for the remainder of her days" (170, app. crit.). The motif of concealment, of wanting to keep to as confined a space as possible, emerges in proportion as Tess's space of repute expands. In Marlott, she looks to be "as much out of observation as possible for reasons of her own" (120), and much of her local movement remains shadowy and concealed. Despite this, the gentle familial "chatter" and "laughter" and "good-humoured innuendoes" (119) meet a more malign version of gossip when Tess attends church and people "turned their heads," "turned them again as the service proceeded" (120), finding her out and whispering to one another: "She knew what their whispers were about, grew sick at heart, and felt that she could come to church no more" (120).

At Talbothays, where Tess first learns about Angel (indeed first hears his name) by way of the nightly gossip whose "whispered words mingled with the shades; and ... seemed to be generated by the darkness in which they floated" (163), her relationship is at once precipitated and threatened by rumor. She articulates a growing sense of impatience with respect to the gossip she imagines to be already,

13 Compare a remark of Hardy's in a letter to George Herriot (10 January 1895) concerning an unpleasant rumor about the purchase of Max Gate: "such gossip annoys me greatly, even when true" (Purdy and Millgate 2: 66). 
at this moment, on its way: "'Why don't somebody tell him all about me?' she said. 'It was only forty miles off-why hasn't it reached here? Somebody must know!'” (252). It is at this point that Hardy's narrator weighs in with a sense of tragic emphasis: "Yet nobody seemed to know; nobody told him" (252). It is as if the only verifiable source for "good report" would have to be preternatural, to issue from on high, a thought expressed by a later, parallel statement regarding Angel's assessment of Tess's "moral value": "No prophet had told him, and he was not prophet enough to tell himself" (369).

Although the sense of anxiety and urgency about discovery may appear natural, it is striking to recall that for at least one early reader this element in the plot was reason for incredulity on specifically social grounds. In her strident review, Margaret Oliphant wondered whether it was "possible that, at a distance of twenty miles at the most, no whisper of such a story should have reached the large rural household with all its connections,-every milkmaid and every man having her and his separate ways of hearing the country gossip" (472). If Marlott lies "within a four hours' journey from London" (19), in a Wessex that Hardy's maps show to be crossed with roads, paths, and even railroads, it would seem evident that such information would be "within easy reach" (Oliphant 472). ${ }^{14}$ This uncertain suspension, though, confirms that what is here at issue is not so much the fact of rumorno fact at all-but rather the fear it ignites. The unease brought about by this practical epistemic situation-merely waiting for testimony to travel—colludes with a rising sense of panic associated with the speed of rumor's movement, the sense that it is already on the move, regardless of geographic distance or the temporal remoteness of past events. Such is the oppressive momentum of the past in a novel that has been said to mourn "the death of yesterday" (Ross 52), where the "coercive presence of the past in the present" intimates the terrible impossibility of escaping "not so much the effects of the past as its repetition" (Miller, Distance 105, 155), a repetition "famed" as well as "fated," already heard about and spoken for.

As her relationship with Angel progresses, through their marriage and increasingly after her confession and their separation, the threat that rumor may unconceal Tess's past becomes linked to the possibility of visual discovery. After Angel reassures her on the matter of the banns— "A licence will be quieter for us" (292) Tess imagines that her wedding dress might nonetheless "betray her by changing colour as her robe had betrayed Queen Guénever" (293). ${ }^{15}$ Certain details in

14 Oliphant considers the issue of repute problematic as well. In complaining about the realism of the events leading up to The Chase, she writes that "a girl brought up in the extraordinary freedom and free-speaking of rural life would scarcely be entirely ignorant of evil; and indeed, as a matter of fact, she has the instinct to discourage and escape as much as possible from the advantages of the seducer and rustic profligate... whose character is well known" (467). She further suggests that when Tess jumps up on the horse with such a character as Alec is reputed to be, she "naturally leaves her reputation behind her" (467).

15 This test of chastity or fidelity was a topos of medieval romance (Firor 297). On the banns (another cognate of fama, as noted above), see Gordon, "Origins" 376 and Ruth A. Firor 233-34. Hardy concerns himself with the publicity of the banns elsewhere, as when Edred Fitzpiers explains to Grace Melbury, "You see, dear, a noisy, bell-ringing marriage at church has this objection in our case; it would be a thing of report a long way round" (Woodlanders 165). 
the novel after this point emphasize the felt necessity of concealment and a dramatic keenness of sensation with regard to discovery, which I address in the next section. Here, it is the social aspect of discovery that is uppermost, as Tess worries about sources of illumination that may issue from afar or from the past. As Angel presses her into responding to his entreaty on a specified day, she breaks away and removes herself to a "thicket of pollard willows ... where she could be quite unseen," only returning after dark and going "upstairs, without a light" $(255,257)$. This vexed concern with staying away from the light colludes with the metaphoric light provided by Angel's attention, which itself "enveloped [Tess] as a photosphere, irradiated her into forgetfulness of her past sorrows, keeping back the gloomy spectres that would persist in their attempts to touch her-doubt, fear, moodiness, care, shame" (280). The past cannot be outrun insofar as it comes in the protean vehicle of hearsay, whether it is thought of as an accusatory light or as "shapes of darkness" "waiting like wolves just outside the circumscribing light" (280). Although Tess "dismissed the past; trod upon it and put it out, as one treads on a coal that is smouldering and dangerous" (276), her solution is at best a temporary one, given that her confession will be attended by exactly this past light- the "Last-Day luridness" and the "red-coaled glow" (318) of ashes in the grate. She will later conceal her wedding ring (391), hide away the fact of her marriage at Flintcomb-Ash where it is a "secret . . or at any rate but dimly known" (434), and on her way to Emminster stop at Evershead to breakfast at a cottage, not in a more public venue, "for she avoided inns" (408).

Tess's confession is, in its way, a mistaken attempt to deflect rumor by way of factual verification. Fama, however, prides itself on erasing the ground of verification as such. She hardly recognizes this key structure governing the epistemology of hearsay, that the "truth" is simply what is said and so cannot be unsaid. After Tess has confessed to Angel, the implied space of operation for rumor explodes from the initial, diminutive square mile to encompass the whole earth as a domain for possible flight. Angel's pained and paranoid exhortations about the future exemplify the impossibility of containing report in a given social space, precisely because it cannot be verifiably bounded. He implicitly contrasts the contagion of repute in a small, delimited area like Marlott with the unpredictability of reputation in larger, unbounded regions-which, considering his colonial ambitions, might include any location from Australia to the Americas. Angel is thinking, he claims, of "the future of other people than ourselves" and tries to cast ahead to the state of affairs that will follow "this past matter getting known-for it must get known," as there "is not an uttermost part of the earth but somebody comes from it or goes to it from elsewhere" (342). This strange "uttermost" intimates at once the spatial reach of Fama and the attendant sense of requiring concealment and recess from public attention-a feeling brought on by the threat of "getting known" but practically helpless against it. ${ }^{16}$ Hardy's narrator here ventriloquizes a criticism

In a previous manuscript version and similarly in the Harper's Bazar serialization, this "uttermost" was confined to "Blackmore Vale and the Chase, even the yonder side of it" (342, app. crit.), a delimited space that was expanded, in the 1891 edition, to include the whole earth. Juliet Grindle and Simon Gatrell comment on how this revision lends weight to Angel's argument 
that Tess might make, but does not: "On an Australian upland or Texan plain who is to know or care about my misfortunes, or to reproach me or you?" (344). This is an astonishing reversal, for both individuals, from the time of their insouciant courtship when Tess had expressed concern should news "reach the ears of your friends at Emminster that you are walking about like this with me, a milkmaid" (278), only to be kindly reprimanded: "[M]y future is to be totally foreign to my family-it will not affect even the surface of their lives. We shall leave this part of England-perhaps England itself-and what does it matter how people regard us here?" (278-79).

I have moved from the expansion and contraction of spaces of agency, and the parallel enlargement and attempted concealment of repute, to the fear of discovery in social space. I now turn to the related question of what will take place after the "matter" is known, the question of "how people regard us," of social opinion and the "world's concern" (128). I want to give more precise shape to this aspect of opinion-which generalizes rumor and social talk into what might be termed the "view from everywhere" and which thereby extends the dynamic of repute to its limit-before I proceed to the internal, bodily sensation accompanying these various social stages. Opinion seems to operate at some distance in this novel, in part because the lower-class groups that are heard gossiping throughout the other novels are confined to the dairymaids and itinerant laborers. In Hardy, these figures often express "a verbalization of the world which is so completely taken for granted that such characters can hardly be said to be individualized or conscious at all," thus providing in their "exact memory for seemingly trivial details of bygone events" (Miller, Distance 106, 107) a vision of how rumors are easily cemented as opinion. In Tess of the d'Urbervilles, we only occasionally feel the presence of observers, who are typically unnamed, self-righteous, and prurient, but there are moments where Tess's "private path inevitably intersects the public language, gossip" (Gordon, "Origins" 372). In one quiet instance of this intersection, the world's report seems to magnify the violence involved in the assault on Tess, while (apparently) verifying that certain details about this event are known to persons other than the two involved, even though these details themselves are the subject matter of hearsay (neither the interlocutors nor the sources are named in this scene). As Tess works in the fields at Marlott, her aspect is discussed by "the woman in the red petticoat" and "the one in buff," one of whom notes of her melancholy: "A little more than persuading had to do wi' the coming o't, I reckon. There were they that heard a sobbing one night last year in The Chase; and it mid ha' gone hard wi' a certain party if folks had come along" (127). ${ }^{17}$ In other instances, the novel imputes

and "throws open the global context, presenting Tess's fraught imagination with a world of willing spies on her and her offspring" (44).

17 This small but significant reply was omitted from the scene in the first edition (1891), producing a striking indeterminacy of voice across the editions, since the third reply in 1891 ("'Twas a thousand pities ...") would be uttered by the first woman, whereas in the one-volume edition (1892), it would seem to belong to the second ("Well, a little more or a little less, 'twas . . ."; 127, app. crit.). Grindle and Gatrell note that this sequence adds "circumstantial vividness to the gossip motif that is a significant element in the fabric of the novel" (46); Mary Jacobus argues 
somewhat bland views to such observers. In Marlott, the narrator even flirts with their general view - that the Durbeyfields "had not been shining examples either of temperance, soberness, or chastity," their "eldest daughter" being the subject of "queer unions" (478). When Tess returns to the village toward the end of the novel, she is "observed almost immediately . . . by some people of scrupulous character and great influence" (479), again unnamed, who will ultimately seek to restore the village to purity and good report, typifying "the power which outraged morality can have over the lives of those who have transgressed social laws" (Pettit 50).

The social background of opinion is present from the novel's first lines, where John Durbeyfield gives the occasional, automatic nod, "as if in confirmation of some opinion" (13), to the "world's opinion," which insists on the distinction between "a liberal education" (139) and Tess's "trouble" (140). The evaluations of others are increasingly felt by Tess as disproportionate to her own withered selfassessment, so that early on she notes Alec's "high opinion" of her in contrast to "her own esteem," in which "she had sunk so low" (60), and later believes that Angel must think her "stupid" in what has become a bodily craving for approval, "an access of hunger for his good opinion" (181). The coercive pressure of opinion, the inability to take advantage of elevated status, and the parallel incapacity to alter a diminished reputation are together articulated in the maxim that it is not "in anybody's power-to feel the whole truth of golden opinions while it is possible to profit by them" (138).

In like fashion, Angel and the members of his family are keenly concerned with opinion, a fact that foreshadows the mismatch between his rigidity and Tess's willingness to compromise. The brothers are seen as more or less tolerant of "contradictory opinion" (229), but Angel is more resistant. He refuses the notion that any view of his parents might modify his intentions (290), and his intransigence is often taken to coincide with his steely views-phrases such as "Clare's own opinion" (363) and "the opinion of Angel" (370) yield the assessment that he holds "extraordinary opinions" (as his brothers see it) and "negative opinions" (as Alec sees it) $(411,439)$. The adamantine views of Angel and the troubled self-esteem of Tess clash after she spends a night in the woods, attending to wounded pheasants and putting into perspective her "sense of condemnation under an arbitrary law of society which had no foundation in Nature" (386). At this moment, she glimpses how her sufferings might be endured "if she could once rise high enough to despise opinion" (387), a formulation that imagines only a different position within the social system of judgment and evaluation rather than an escape from it. Still less can Tess envision a way out, since the sensation of being watched has blurred the world's assessment of her to coincide with that of Angel. The combined view she imagines is considerably more monstrous, and she cannot bear its pressure, especially "so long as it was held by Clare" (387). Opinion maximizes the social expansion of the sphere of repute, but it is through its bodily registra-

that the revelation is one of several modifications to the novel after 1889, many of which take part in what she terms the "purification" of Tess (328). This episode is crucial to discussions of whether Alec's actions in the Chase can be reliably determined as rape or seduction; see especially Ellen Rooney 97-100 and William A. Davis 228-29. 
tion that the novel, I will suggest, discovers the "high enough" that might escape rumor's nets to be terribly high indeed.

"Ocular Beams": The Physiology and Sensation of Rumor

Always act as if you were in full view. He is a man of insight who sees that he is seen or that he will be seen.

—Gracián

The course of the novel magnifies the pressure of discovery and the fear of opinion into a set of physiological events in the bodies of its characters, often emphasized by Hardy and sometimes felt by them as conscious sensations. ${ }^{18}$ As these sensations become more vivid, the pulse of shame felt by Tess-the dialectic between self-presence and self-presentation, between her sensations and moral emotions and the social aspect she shows to the world-begins to lose the skeptical clarity it seemed to have earlier. For example, when she returns to Marlott, it is suggested that Tess "might have seen that what had bowed her head so profoundly-the thought of the world's concern at her situation-was founded on an illusion," since she cannot be considered "an existence, an experience, a passion, a structure of sensations, to anybody but herself" (128). The division here between Tess's "conventional aspect" and her "innate sensations" (128) is an uneven one, since whatever might be placed on the former side (of the worldly and "conventional," of opinion and repute) is exceeded by the acuteness and persistence of whatever occupies the latter. That the word "sensations" might work in the semantic register of scandal and social agitation suggests that the views, opinions, and rumors of the world, however baseless, may come to be felt in the interior of the body with particular vivacity. In this section, I track the physiological transformations and sensations occasioned by rumor - in both visual and aural registers-as it looks to secure a bodily verifiability distinct from, and often in contravention of, its status in the social sphere.

Tess's first attempts at self-concealment and holding herself "aloof" almost achieve the desired goal, for "her trouble, never generally known, was nearly forgotten in Marlott" (140). Yet this fact is irrelevant to her general malaise, her sense that she "could not be comfortable there till long years should have obliterated her keen consciousness" (140) of the "trouble" that the world insists is hers. Tess moves from being seen only insofar as she is unseen or overseen-as when Angel chooses to dance with another at the May-walking dance-to having her acute sense of being seen drive her actions. Angel feels, after the dance, that "she was hurt by his oversight" (26). This word can already be read ambivalently as an "oversight" either of omission or of surveillance, both of which have the capacity to

18 Hardy copied out this maxim of Gracián's (Notebooks 1: 973) from a digest translated by M. E. Grant Duff (341) and published in the March 1877 number of the Fortnightly Review, where a part of Tess of the d'Urbervilles was later published as "The Midnight Baptism" (see Appendix $2,553-59)$. 
injure. Increasingly during the course of the novel, Tess feels the pressure of being watched, of having eyes upon her, as when Alec follows her, and her back "seemed to be endowed with a sensitiveness to ocular beams-even her clothing-so alive was she to a fancied gaze which might be resting upon her" (421). In this example, a material detail is significant. As Tess returns from Emminster, she is wearing the last of the clothes given to her by Angel, "as if she is wearing him" (Gatrell 150). The "almost physical sense of an implacable past which still engirdled her" thus entails, in sensation, a number of different levels: she is weighted down and encircled by Angel; pressed by the gaze of Alec; and haunted by a felt "consciousness of error" that is so disabling as to amount to "a practical despair" (421). Past injuries and present accusations take on a physical form, certainly for Tess but for others as well in this "world full of watching eyes" (Tanner 233) and "intense mutual looking, inspecting, and scrutinizing" (Cunningham 555). The setting typifies the wider Victorian era's "vigilance over the physical" (Poole 339), predicating Tess's fate "on whether and how she is seen" (Freeman 315). ${ }^{19}$ The characters recognize, in some measure, these constraints and intensities. At Flintcomb-Ash, Alec turns away from the pressure of Tess's eyes, saying "Tess-don't look at me so-I cannot stand your looks! There never were such eyes, surely, before Christianity or since!" (434). Even inanimate objects and parts of the landscape seem suffused with a capacity to watch and take note: the buttons on the trousers of a working man "twinkled and bristled with sunbeams ... as if they were a pair of eyes in the small of his back" (124); and Tess asks Angel in the fields at Talbothays, "The trees have inquisitive eyes, haven't they?- - that is, seem as if they had" (177).

Despite this visual pressure, there is still a sense-a hope or belief-that rumor might keep its distance, thereby allowing a respite from the pressing constraint of the sensations it brings about. When Tess and Angel marry, the few attendees present at the ceremony are described as being at "stellar distances" (302). The "sphere" of rumor has, here, been pushed away to the distance of the spheres, a temporary fiction that persists through the escape from Sandbourne to the purportedly isolated space of Stonehenge. But even pale, sidereal light can align itself with the searchlights of Fama. When Angel and Tess sit down to their first "common meal," the sun "shone in through a small opening and formed a golden staff which stretched across to her skirt, where it made a spot like a paint-mark set upon her" (309). ${ }^{20}$ This detail can be set against the recurrent emphasis on moral insignia of a similar sort: the "smudge" Tess thinks she has set upon her family's name (131); the physical "blemishes which sunlight might have revealed" (133) on

On looks and looking in the novel, see J. Hillis Miller's cogent reading of the many scenes in which individuals spy on or watch others (Distance 119-24) and Freeman's argument that "from having once been seen, all the rest will strictly follow" (313).

20 The "paint-mark" is a manuscript revision of "permanent mark," as an earlier version reads (309, app. crit.). This connection has been variously noted. Miller considers the range of figures surrounding "the tracing of a pattern, the making of a mark, the carving of a line or sign, and the act of writing" (Fiction 118), and Kaja Silverman characterizes the mark as an "inscription" and the sign of a "mastering gaze" (8-9). 
her work-worn arms; the "sticky blights" and "madder stains" that mark her as she walks in the garden (175). ${ }^{21}$ Perhaps more striking is that the filament of sunlight indexes a permanent change, a "paint-mark" that surely recalls the signal example of paint in the novel, the "staring vermillion words"- "THY, DAMNATION, SLUMBERETH, NOT" - that "seemed to shout themselves out, and make the atmosphere ring" (113) throughout the countryside, mimicking the persistence of rumor as it here moves from social space and arrives at the surface of its bodily target. ${ }^{22}$

When such instances of illumination do not seem to have an acute physiological result, they provide the significant and radiant backdrop against which more vivid sensations will be felt. The passage of the sun, for example-the encroachment whereby shadows start long, reduce to a point, and lengthen out again in the diurnal rhythm - gives a precise character to the novel's settings. The simple background of the dairy makes visible a daily routine that, crucially, breaks the frame of day and night, so that workers are up before dawn, breakfasting after they have worked for a couple of hours, sleeping in the middle of the day, and finding in twilight a more significant phenomenon than night. Tess begins as "sun-blessed" and ends "sacrificed to the sun" (Tanner 227, 228), and in between we have a succession of sun moments, from Angel's proposal to the scene of their first meal together, from the sun illuminating the bed in their fugitive house to the final discovery at Stonehenge. The sun also provides a hidden text to the plot in the remarkable "Morning Hymn" (120) to which Tess listens in church. Hardy does not provide the text, but in a hymn that implores its listeners to "Wake, and lift up thy self, my Heart, / And with the Angels bear thy part" (just prior to Tess's meeting Angel Clare), one especially sun-struck verse stands out:

Awake my Soul, and with the Sun,

Thy daily stage of Duty run;

Shake off dull Sloth, and early rise,

To pay Thy morning Sacrifice. (Ken 141-45)

Sunlight thus comes to define an illumination that Angel and Tess cannot see-or cannot see in all its significance-and it often wears "a curious, sentient, personal look" (122). At one point during their courtship, they walk in the late

21 Grindle and Gatrell prefer this reading, drawn from the final edition of 1912. However, both the manuscript and 1891 versions read "blood-red stains" (175, app. crit.), which reinforces Hardy's attention to the bodily component in moral action and assessment. As Philip M. Weinstein notes of this scene, Hardy's world "is no discarnate vacuum for the transcendental spirit but a material plenitude, teeming with all strata of living creatures, marked by ineradicable stain, humming with cross-pollenization" (119).

22 An alternate message appears in the manuscript: "THE, WAGES, OF, SIN, IS, DEATH" (113, app. crit.). See Ronald J. Nelson's discussion of the sign painter's appearances in the novel (60-69) and Silverman's contention that the sign painter both "marks" and "constructs" Tess (11-12). Other examples of significant painted objects in the novel include the turnip-slicing machine, "whose bright blue hue of new paint seemed almost vocal in the otherwise subdued scene" (430; emphasis added). 
afternoon so that their shadows "stretch a quarter of a mile ahead of them, like two long fingers pointing afar" (278). Ominously, the light casts a shadow ahead of them and so throws light on their backs, allowing others to see what they cannot; further, these "fingers" of shadow, which stretch out to a precise distance, suggest that other fingers might be pointing back at them. Simply standing in the sunlight casts a wide circle of exposure and potential report, outshining Tess's entire existence at Marlott, where she remained with a meager "square mile" of "repute."

Even where the space of reputation is set back as far as the sun and stars-casting only an uncertain light that might be temporarily shielded from sight-the very distance its light must travel reveals the broadened circumference of Fama, whose reach has attained the heavens. The sensation of rumor's impress now feels as unbearable as it is unavoidable. From the space of a square mile to the space of the world, the dynamic of repute returns, magnifying our notice of the agent, widening the domain in which such notice can take place, and igniting a painful sense of social translucency and moral self-presence. The physiology of rumor-its disruption of pulse, temperature, and breathing-even mirrors its social magnification, at one point rising to a degree of scientific objectivity as emotion causes a tear to roll over Tess's cheek, a tear "so large that it magnified the pores of the skin over which it rolled, like the object-lens of a microscope" (327). Rumor begins with the expansion of social repute and ends by turning that amplification back to bodily surfaces and states, to moral sensations and emotions.

If the visual aspect of rumor's "sensation" looks most glaring, there is also an undercurrent that follows what swirls around reputation as sound and noise, things heard and overheard, exemplifying what Hardy calls "the independent personality of the tongue" (Woodlanders 56). At several key moments, characters sense that they are being not only watched but also heard. They may even whirl round to verify such a premonition, as when Alec addresses Tess on the ricks and looks round "to see if he were overheard," despite the fact that distance and noise block his words from "reaching other ears" (431). His is the voice, we have just been reminded, that "had brought to her ears expressions of such divergent purpose" (419) as he tried to persuade Tess of the authenticity of his suit. After she reveals to him the fact of her marriage, sound breaks up the scene: Farmer Groby returns with a "pattering of hoofs on the soil of the field," and "a voice reached her ear" (435) in a small-scale dramatization of the linked concerns of looking and being looked at, of hearing and being heard.

More than once, sensation colludes from within to block Tess's ears, so that her "feelings almost filled her ears like a babble of waves, and surged up to her eyes" (279), just as "every wave of her blood, every pulse singing in her ears, was a voice that joined with Nature in revolt against her scrupulousness" (255). Rumor, now actualized as a swell, a physical substance inside the body, returns as noise-at Sandbourne, where the sea "murmured, and [Angel] thought it was the pines; the pines murmured in precisely the same tones, and he thought they were the sea" (511); and at Stonehenge, with which the fleeing couple almost collide: 
"What monstrous place is this?" said Angel.

"It hums," said she. "Hearken!"

He listened. The wind, playing upon the edifice, produced a booming tune, like the note of some gigantic one-stringed harp. . . . They carefully entered beneath and between; the surfaces echoed their soft rustle; but they seemed to be still out-of-doors. The place was roofless. Tess drew her breath fearfully, and Angel, perplexed, said "What can it be?". . .

"A very Temple of the Winds," he said. (534-35)

The visual and the aural here converge, for this "Temple of the Winds," humming and distributing noise through the landscape, is also designed to channel the sun's rays. The sphere of Tess's movement has finally retreated so that she no longer has, as it were, any radius at all, and instead sits at the center of a circular formation that appears as a target in the landscape. Having achieved its social expansion, rumor now compels the sensation of bodily contraction, as Tess feels her sphere of agency shrink. It may be useful to recall the various constraining circles that run through the novel, from the fat around John Durbeyfield's heart, the danger of which is symbolized by his wife closing her fingers "into a circle complete" (30), to Tess's hair as an "immense rope . . like a ship's cable" (366), which likewise presages the noose that will end her life. These images figure Tess's retreat from a wide public sphere to a physiological vanishing point, as the visual and aural elements of rumor-its winds and whispers, its "oversight" and "ocular beams" - serve to contract the space of repute, making social and narrative forces felt as acute sensations. It is as though Tess experiences the social equivalentwhen the strictures of scruple and moral censure take physical form-of what small field creatures feel, flushed out during the corn harvesting, "unaware of the ephemeral nature of their refuge" and edged into a "more and more horrible narrowness" (124) with no escape in sight.

\section{"Wounded Name": The Afterlife of Repute}

I have shown how rumor accompanies the movement of characters-that rumor is on the move is perhaps the most confirmable attribute it presents-and how its expansive mobility is registered by those it touches as unflinchingly verifiable. The external, social facts of reputation come to be reflected in the felt "facts" of internal sensations. Yet rumor goes further still, activating sensation directly by attacking one's name, thereby transforming the index of that which is paradigmatically contingent and imposed from without into a necessary identity felt from within. In this last section, I suggest that rumor's "sensation" turns the very instability of the novel's names into firm and necessary facts felt in the body, conjoining social and corporeal representations while adding to narrative pressures and moral encumbrances that are curiously thought to continue even after the target of rumor vanishes from the world.

In 1891, Hardy sent a final-hour revision to the publisher of Tess of the d'Urbervilles in the form of a new title page, with an epigraph drawn from The Two Gentlemen 
of Verona: "Poor wounded name! My bosom, as a bed, shall lodge thee." ${ }^{23}$ Whatever the broader interpretive issues raised by this document, it at least serves to emphasize the place of names in the novel, their stature and precision (or otherwise), their invocation in legal senses and moral situations. The misfortunes of Tess are initially mobilized after her father looks to assume his more authentic name and the status it might confer on his family. For Tess and Angel, remarkable consequences follow from "writing his name in a church-book beside hers" (405). She expresses concern at whether she has a "moral right" to be "Mrs Angel Clare" when she may also answer to "Mrs Alexander d'Urberville" (304), as though the contract of marriage could only be divided along such stark nominal lines, into a verbal agreement and a bodily ratification. Whether they attach to things, settlements, or locales; to an animal ("Prince") or several animals (the dairy cows); or to a person occupying the narrative or made allegorical with respect to it ("Sorrow"), it is often of vital import who remembers whose name, at which moment, from what source, and which names might be revealed to whom. ${ }^{24}$ Although characters in Hardy might "never encounter a bare, nameless river, heath, hill, or wood" (Miller, Distance 105), the narrative of Tess of the d'Urbervilles frames itself as curiously disadvantaged in this respect, unable to offer a complete set of names since some have "not been handed down" (25).

The course of the plot dramatically undermines the stability of names, blurring the "name of Durbeyfield" and "the name of d'Urberville" (511), offering multiple names, nicknames, and "pet name[s]" (191) for its characters, variously signing and alternating "Christian" (512) and family names, "maiden" (511) and married names. In a manuscript variant, Tess briefly reverts to calling her husband "Mr Clare" just as she realizes he cannot licitly divorce her (337, app. crit.), and Angel continually tries to assign other names to Tess, be they nicknames ("Tessy" is used often) or mythological types and "fanciful names," such as "Demeter" or "Artemis" (186). Hardy also employs strange abstractions that clothe her name in mediation, as in "such a woman as Tess" (465). ${ }^{25}$ The novel also offers a boy whose family was not "stablished long enough" to have "had any surname" (182) against the long shadow of the d'Urberville name, highlighting the difference between what Tess and her family view as "a family name [that] came by nature" (52) - hence a "real name" (30)—and the artificial "annexations" that compound "Stoke" to the nobler "d'Urberville" for utilitarian ends (52). In general, then, the novel would seem to attribute to naming the force of what O'Toole has called "narrative coercion," for

23 For an account of the publishing and serialization wrangles over Tess of the d'Urbervilles, see Michael Millgate 300-302; Jacobus 325 on the "campaign to purify Tess" after rejections; and J. T. Laird's extensive discussion of the novel's genesis and publishing history.

24 William Greenslade notes that the "myth of pedigree" is central to the novel's plot and suggests that notions of pedigree, stock, and heredity played a role in the revision process of the novel (111-14). O'Toole similarly considers the novel with respect to names, family history, and genealogy (75-92).

25 Consider also Hardy's trial versions of the heroine's name, including "Rose-Mary," "Sue," "Cis," "Love," and, in "The Midnight Baptism," "Beauty" (see app. crit., 553-59, 562). 
naming is a means of exercising "power over another by assigning him or her to a particular narrative" (56).

But one's name may exert coercive force in another, more covert way, by becoming the target of rumor. The novel emphasizes and attends to such targeting in the form of scandal. When, after the failed honeymoon, Tess confesses that she contemplated suicide but could not carry the action through because "it might cause a scandal to your name" (337), she airs a view that is widely shared. Angel, too, says that the couple should stay together "to avoid the scandal to [her] that would have resulted from [their] immediate parting" (341). It is crucial to note, though, that this sense of scandal registers as a physical danger, as though the stable index of one's name were located in the body. Tess avoids mentioning her husband when she finds work, not wanting "to bring his name down to the dirt" (391) and later tries to rid herself of Alec "before any scandal spreads that may do harm to [Angel's] honest name" (442), a conviction alluded to later when Alec's having "called [Angel] by a foul name" becomes the motive for his death (524).

In spite of the fearful reticence of characters regarding their names, however, rumor still tracks its targets mercilessly, turning the very imprecision of their names into a ruse for identifying them all the more exactly. Set against the dispersal of names and the anxiety regarding their exposure and publication, it seems significant that even Hardy's epigraphic allusion might gesture toward another name and a different source. The phrase "wounded name" occurs only once elsewhere, in Shakespeare, only once, in the voice of the Prince of Denmark as he lies on the threshold of death and considers the status of his "name" and "story":

\section{O good Horatio, what a wounded name, \\ Things standing thus unknown, shall live behind me! \\ If thou didst ever hold me in thy heart \\ Absent thee from felicity awhile, \\ And in this harsh world draw thy breath in pain, \\ To tell my story. (Hamlet 5.2.349-54)}

Hamlet's concern with the distinction between a wounded and a forgotten name is key in Hardy's world, where protagonists "forget nothing, nor do those who can make them suffer ever disappear" (Weinstein 122). It is of considerable distress to Angel—who alludes to Hamlet at least once (239) — that "that bit of distinction in poor Tess's blood and name" will "soon be forgotten" (465), although he hardly adopts the position of Horatio.

There is an important sense in which Tess may prefer such effacement to the glaring light of rumor. Hardy gave voice to this feeling in the striking poem that adopts her as a lyric presence, "Tess's Lament" (Poems 161-62), written in 1899 (Taylor 44). The poem concerns itself with what J. Hillis Miller has identified as the "strange wish for this ultimate form of vanishing" as it exercises Hardy in many places in his work (Distance 220-22), but it is in the context of rumor that its melancholy finds especial poignancy. The insistent sentiment declared by the opening lines—“I would that folk forgot me quite, / Forgot me quite!" (11. 1-2)_ can, for instance, be set against the physical constraint that, in the form of slander 
and hearsay, at once drives Tess (and thus the lyric "Tess") to wish for this kind of effacement, compelling a kind of brave indignation against rumors that might hold sway after death. The axis of rumor allows us to see how "Tess," a figure from beyond the grave, cannot quite decide between two extremes-desiring a traceless disappearance from the record of existence, on one hand, and wanting a retroactive clearing of her name, on the other. The first extreme forms the closing stanza of the poem:

\section{It wears me out to think of it, \\ To think of it; \\ I cannot bear my fate as writ, \\ I'd have my life unbe; \\ Would turn my memory to a blot, \\ Make every relic of me rot, \\ My doings be as they were not, \\ And gone all trace of me! (11. 41-48)}

Escaping a "fate as writ" appears in a set of impossible formulations: that achieved actions be unraveled, "be as they were not"; that an "I" who took up a grammatical position escape the existence implied by grammar and have its "life unbe"; and that obscuring memory to a mere "blot" on the page still not appear as a "trace." 26 The aggregate of such wishes for self-vanishing can also be seen as the result of wishes concerning the second extreme-that is, an obsession with the afterlife of name and repute when one's radius has finally been contracted to a point in one final movement, of six feet, into the ground. In the first stanza, for example, we have a post facto confirmation of the insidious connection between Tess's fear of discovery and illumination: "I would that I could shrink from sight, / And no more see the sun" (11. 3-4). ${ }^{27}$ In her desire for retreat, however, to "claim my nook," the lyric voice also concerns itself with those who remain-“"I wonder what they say o'us now, / And if they know my lot"-and goes so far as to ascribe a sense of responsibility to the still-living: "Time for them all to stand and tell / Of my day's work as done" (11. 6, 37-38, 7-8). These lines have the character of an injunction- "stand and tell" - that matches Hamlet's dying wish to preclude affairs from "standing unknown" as he implores Horatio to "tell my story." In lyric whether she has been, and now wants to cease to be, or has never really been," a tension that issues from the prefix un- expressing both negation and reversal (258). See also O'Toole 75-76.

Hardy may be echoing the song of Guiderius in Cymbeline:

Fear no more the heat $o^{\prime}$ th' sun

Nor the furious winter's rages;

Thou thy worldly task hast done,

Home art gone, and ta'en thy wages. (4.2.258-61)

It counsels, a few lines later: "Fear not slander, censure rash" (272). 
space, "Tess" finds the possibility of a restorative testimony that is foreclosed in the novel, where confession only serves to stoke the fire of scandal.

The thoughts articulated by "Tess's Lament" find significant shape in several other poems, ${ }^{28}$ most notably in the late poem "A Private Man on Public Men" (Poems 885), where the narrator thinks of his "contemporaries" and their "fames" "fanned / By rumour's tongue throughout the land"-and contrasts his own position, as one who lives "in quiet, screened, unknown" (1l. 1, 7-8, 9). In a similar way, in a poem that seems almost a companion to "Tess's Lament," "The To-BeForgotten" (Poems 131), the speaker considers his friends in the graves around, "screened from life's unrest" (1. 4). In "A Private Man," though, the aspect of noise, of chatters and whispers that haunt the border between the living and the dead, is brought out fully:

Shut from the noise of the world without,

Hearing but dimly its rush and rout,

Unenvying those amid its roar,

Little endowed, not wanting more. (11. 17-20)

As Hardy imagines those put to a final silence-simultaneously shut out and yet hearing, still considering though not envying the "noise of the world without"we see the strange reversibility of rumor after death. During life, a character's personality (even in the privacy of sensation) could "in some essential way be shaped by the scandalous rumors which the world perpetuates," as Kenneth Gross puts it, "deformed by what Montaigne calls 'this breathie confusion of bruits, and frothy chaos of reports and vulgar opinions'" (47). In death, this rumored projection of personality remains in the world and is imagined as still occupying the minds of the deceased in their graves. The pulse with which I began-repute flooding outward in space as the index of social self-presentation and repute retreating back in shame and fear as the paradigm of bodily self-presence-comes to a rest after death. Yet what a pained and hounded rest it seems, purchased only after cowering sensibly before the eyes of accusation and the ears of hearsay, after the annihilation and effacing that rumor entails. For in Tess of the d'Urbervilles, Fama can only retract the translucency it has made its victims feel, can only remove the searing sense of being watched, heard, and followed to the ends of the world after the close of the novel, when Tess Durbeyfield has finally risen above the tide of opinion-become a name with no bodily referent-and made her way "To that land whence / No rumour reaches us" (Poems 158, 11. 76-77).

By means of a force actualized in the sensations of the body, Fama impels the movement of this novel from within, acting as the groundswell of those broader social and moral pressures usually classed under the sign of fate. In following its movements, treating rumor almost as a character in itself (less than minor, would add such poems as "The Well-Beloved," "The Ruined Maid," "A Hurried Meeting," and "Not Known." 
more than central), I have outlined its influence on minute narrative dynamics and shown how its looming presence bridges the larger distance between social judgments and their refraction in the body. In the insistent and malign nexus between bodily events and social determinations, rumor has also disclosed a crucially embodied view of moral psychology - of moral attitudes, motivations, and actions, particularly in its ignition of moral emotions such as pride and shame. Attending at once to the vexing epistemological status of rumor's ethical "evidence" and to what might be called its "sensation" account of moral psychology might, I suggest in closing, yield insights for novel criticism more broadly.

If rumor injures by rendering "fictions" where we might expect "persons," making literature its natural domain and novelists its chief promulgators, then criticism is uniquely poised (in contrast to social psychology or philosophy) to investigate its mechanics and moral stakes. By reflecting on the representational layers that mediate between fictions and persons, and on the nature of the "evidence" entailed in such layers, we call attention to forms of mediation-to prejudices, filters, omissions-often present in habitual moral life. And if rumor's indirections divide agents from their potentially harmful words, disseminating unverifiable evidence and making possible an agentless damage that is nevertheless brought about by persons and keenly "verified" in the body, then attempting to see through and with its fictionality-its epistemological screen-might alert us to further ravages of injurious language, both within novels and without. Conversely, in addressing worlds populated by fictions, novel critics might be thought to practice a corrective to rumor on its own terrain-inverting injury not by unsaying or indicting what has been said but by reinscribing "fictions" as "persons," exposing the moral penumbra at the edge of rumor's operations, and renewing attention to moral attitudes in the embodied, affective dimensions that gossip only just brings to light. Instead of following the empirical dynamics of rumor-considering how it distorts information or twines its way through a social network, thus tacitly underwriting the convertibility of persons and fictions-we can cross-examine rumor's more minute, sensed effects. Deflecting notice to the felt significance of language in the body, criticism can show how, in the "knowledge" on which it relies and the bodily register in which it takes effect, rumor alerts us to unnoticed shades of moral life.

A number of critics have fashioned a more positive and reconstructive picture of rumor, praising its social energies, communal as well as subversive, and adverting to its "special usefulness for subordinated classes" in creating "a discourse potentially challenging to public assumptions" (Spacks, Gossip 46). In recasting rumor in an inimical light, I have sought neither to deny the value of such recuperations nor merely to reprise the moralizing censure that has long been leveled at such talk. I have, rather, aimed to take seriously both rumor's motivating power-however ill judged - in the moral psychology of novels and the species of intuitive and unverifiable evidence it makes visible. Commenting on the fear of gossip, Spacks argues that "condemnation" of such talk is typically "based less on evidence than on surmise" (Gossip 29) — but so, we have seen, is the phenomenon itself. To take rumor as an analytical category, as I have done, is to be sensitive to a type of evidence that exists apart from verification, a testimony that comes at 
second hand, heard on the wind and felt in the body, a matter of unreliable witnesses and probable opinions. Such "hearsay evidence" is generally inadmissible in a court of law, yet it forms the ground by which we make and become the targets of moral judgments, in novels and criticism as in our felt exposure to the "huge whispering-gallery" (Eliot 402) that is the world.

\section{Works Cited}

Agamben, Giorgio. The Time That Remains: A Commentary on the Letter to the Romans. Trans. Patricia Dailey. Stanford: Stanford UP, 2005.

Bayley, John. An Essay on Hardy. Cambridge: Cambridge UP, 1978.

Cunningham, Valentine. "Tess." The Novel, Volume 2: Forms and Themes. Ed. Franco Moretti. Princeton: Princeton UP, 2006. 548-58.

Davis, William A., Jr. "The Rape of Tess: Hardy, English Law, and the Case for Sexual Assault." Nineteenth-Century Literature 52.2 (1997): 221-31 <doi:10.2307/2933908>.

Eliot, George. Middlemarch. Ed. David Carroll. Oxford: Clarendon, 1986.

Ernout, Alfred, and Antoine Meillet. Dictionnaire étymologique de la langue latine. 4th ed. Paris: Klincksieck, 1979.

Fenster, Thelma, and Daniel Lord Smail. Introduction. Fama: The Politics of Talk and Reputation in Medieval Europe. Ed. Thelma Fenster and Daniel Lord Smail. Ithaca: Cornell UP, 2003. 1-11.

Fenves, Peter D. "Chatter": Language and History in Kierkegaard. Stanford: Stanford UP, 1993.

Firor, Ruth A. Folkways in Thomas Hardy. Philadelphia: U of Pennsylvania P, 1931.

Freeman, Janet. “Ways of Looking at Tess." Studies in Philology 79.3 (1982): 311-23.

Gatrell, Simon. "Dress, Body, and Psyche in 'The Romantic Adventures of a Milkmaid,' Tess of the d'Urbervilles, and The Mayor of Casterbridge." Thomas Hardy Journal 22 (2006): 143-58.

Glare, P. G. W., ed. Oxford Latin Dictionary. Rev. ed. Oxford: Clarendon, 1996.

Gordon, Jan B. “Gossip and the Letter: Ideologies of 'Restoration' in Jude the Obscure." Lore and Language 8.1 (1989): 45-80.

“Origins, History, and the Reconstitution of Family: Tess' Journey." ELH 43.3 (1976): 366-88 <doi:10.2307/2872420>.

Grant Duff, M. E. “Balthasar Gracian [sic].” Fortnightly Review 21 (1877): 328-42.

Greenslade, William. "The Lure of Pedigree in Tess of the d'Urbervilles." Thomas Hardy Journal 7.3 (1991): 103-15.

Grindle, Juliet, and Simon Gatrell. General Introduction. Tess of the d'Urbervilles. Ed. Juliet Grindle and Simon Gatrell. Oxford: Clarendon, 1983. 1-54. 
Gross, Kenneth. "The Rumor of Hamlet.” Raritan 14.2 (1994): 43-67.

Hardy, Florence Emily. The Life of Thomas Hardy, 1840-1928. London: Macmillan, 1962.

Hardy, Thomas. Collected Poems of Thomas Hardy. London: Macmillan, 1930.

—. Tess of the d'Urbervilles. Ed. Juliet Grindle and Simon Gatrell. Oxford: Clarendon, 1983.

York UP, 1985.

—. The Woodlanders. Ed. James Gibson. Harmondsworth: Penguin, 1981.

Isidore. Isidori Hispalensis episcopi Etymologiarum sive Originum. Ed. W. M. Lindsay. 2 vols. Oxford: Clarendon, 1962.

. The Etymologies of Isidore of Seville. Trans. Stephen A. Barney, W. J. Lewis, J. A. Beach, and Oliver Berghof. Cambridge: Cambridge UP, 2006.

Jacobus, Mary. "Tess's Purity." Essays in Criticism 26.4 (1976): 318-38. <doi:10.1093/eic /XXVI.4.318>.

Ken, Thomas. A Manual of Prayers for the Use of the Scholars of Winchester College, and All Other Devout Christians. London, 1695.

King, R. W. "Verse and Prose Parallels in the Work of Thomas Hardy." Review of English Studies 13.49 (1962): 52-61 <doi:10.1093/res/XIII.49.52>.

Laird, J. T. The Shaping of Tess of the d'Urbervilles. Oxford: Clarendon, 1975.

Lewis, Charlton T., and Charles Short, eds. A Latin Dictionary. Oxford: Clarendon, 1879.

Liddell, Henry George, and Robert Scott, eds. A Greek-English Lexicon. 9th ed. Oxford: Clarendon, 1996.

Miller, J. Hillis. Fiction and Repetition: Seven English Novels. Cambridge: Harvard UP, 1982.

—. Thomas Hardy: Distance and Desire. Cambridge: Belknap P of Harvard UP, 1970.

Millgate, Michael. Thomas Hardy: A Biography. Rev. ed. Oxford: Clarendon, 1992.

Nelson, Ronald J. “Stirring Up Trouble: The Sign Painter in Hardy's Tess of the d'Urbervilles." Thomas Hardy Journal 15.2 (1999): 60-71.

O'Toole, Tess. Genealogy and Fiction in Hardy: Family Lineage and Narrative Lines. Basingstoke: Macmillan, 1997.

[Oliphant, Margaret.] “The Old Saloon.” Blackwood's Edinburgh Magazine 151 (Mar. 1892): $455-74$.

Pettit, Charles P. C. "Hardy's Concept of Purity in Tess of the d'Urbervilles." Thomas Hardy Journal 7.3 (1991): 49-56. 
Poole, Adrian. “'Men's Words' and Hardy's Women." Essays in Criticism 31.4 (1981): 328-45. $<$ doi:10.1093/eic/XXXI.4.328>.

Purdy, Richard Little, and Michael Millgate, eds. The Collected Letters of Thomas Hardy. 7 vols. Oxford: Clarendon, 1978.

Rooney, Ellen. "'A Little More than Persuading': Tess and the Subject of Sexual Violence." Rape and Representation. Ed. Lynn A. Higgins and Brenda R. Silver. New York: Columbia UP, 1991. 87-114.

Ross, Jody Gallagher. "The Irrecoverable Past in Tess of the d'Urbervilles." Thomas Hardy Journal 4.1 (2008): 44-53.

Salter, C. H. “Unusual Words Beginning with Un, En, Out, Up, and On in Thomas Hardy's Verse." Victorian Poetry 11.3 (1973): 257-61.

Shakespeare, William. Cymbeline. Ed. J. M. Nosworthy. London: Methuen, 1955.

—. Hamlet. Ed. Harold Jenkins. London: Methuen, 1982.

—. The Second Part of King Henry IV. Ed. A. R. Humphreys. London: Methuen, 1966.

Silverman, Kaja. "History, Figuration, and Female Subjectivity in Tess of the d'Urbervilles." Novel 18.1 (1984): 5-28.

Simpson, J. A., and E. S. C. Weiner, eds. The Oxford English Dictionary. 2nd ed. Oxford: Oxford UP, 1989.

Spacks, Patricia Meyer. Gossip. New York: Knopf, 1985.

—_. "In Praise of Gossip." Hudson Review 35.1 (1982): 19-38 < doi:10.2307/3851309>.

Tanner, Tony. "Colour and Movement in Hardy's Tess of the d'Urbervilles." Critical Quarterly 10.3 (1968): 219-39 <doi:10.1111/j.1467-8705.1968.tb01982.x>.

Taylor, Dennis. “The Chronology of Hardy's Poetry.” Victorian Poetry 37.1 (1999): 1-58.

The Holy Bible, Containing the Old and New Testaments. London: Eyre and Spottiswoode, 1859.

Vaan, Michiel de. Etymological Dictionary of Latin and the Other Italic Languages. Leiden: Brill, 2008.

Vermeule, Blakey. "Gossip and Literary Narrative." Philosophy and Literature 30.1 (2006): 102-17 < doi:10.1353/phl.2006.0021>.

Virgil. Opera. Ed. R. A. B. Mynors. Oxford: Clarendon, 1972.

—. The Works of Virgil. Trans. John Dryden. London: Warne, 1877.

Weinstein, Philip M. The Semantics of Desire: Changing Models of Identity from Dickens to Joyce. Princeton: Princeton UP, 1984.

Williams, Bernard. Shame and Necessity. Berkeley: U of California P, 1993. 